\title{
THE ETHICS OF TAX EVASION: A SURVEY OF HISPANIC OPINION
}

\author{
Robert W. McGee, Florida International University \\ Arsen M. Djatej, Eastern Washington University \\ Robert H. S. Sarikas, Ohio University
}

\begin{abstract}
The present paper is an empirical study, the goal of which is to determine the strength of various arguments that have been used to justify tax evasion and to determine whether results differ based on certain demographic variables. A survey instrument was constructed using a seven-point Likert and distributed to 316 business students at a university in South Texas. The 18 arguments were ranked in terms of strength, from strongest to weakest. Comparisons were also made according to gender, age, and academic major to determine if the viewpoints for these demographics were significantly different. Academic major was the only demographic variable where significant differences in opinion were found. For some of the 18 arguments justifying tax evasion, accounting students were significantly more averse to tax evasion than were business and economics majors. Some arguments justifying tax evasion were stronger than others. The strongest arguments for evading taxes were in cases where the government engaged in human rights abuses. Other strong arguments were in cases where the tax system was perceived as unfair, where tax rates were too high, where government officials were corrupt or where tax funds were not spent wisely.
\end{abstract}

JEL: H26; J1; J14; J15; J16; K34; M4

KEYWORDS: tax evasion, Hispanic, gender, age, major, demographic

\section{INTRODUCTION}

$\mathrm{T}$ The research issue we focus on is tax evasion. Tax revenues are important because the governmental services necessary for modern civilization must be funded by tax revenues. More government services could be provided if there was no tax evasion. Joel Slemrod (2007) has noted that determining the extent of tax evasion is not straightforward. He observes that the most careful and comprehensive estimates of the extent of tax compliance have been made by the U.S. Internal Revenue Service (IRS). The dollar estimate of annual tax evasion is labeled as the "tax gap" by the IRS. A 2009 Department of Treasury document (no author designated) reports that for Tax Year 2001 the "tax gap" was $\$ 345$ billion dollars. Further the IRS observes this represents a noncompliance rate of $16.3 \%$. Detail in the document reveals that over $\$ 255$ billion dollars of the total tax gap is due to the individual income tax, which suggests that studying individual attitudes toward tax evasion is most appropriate.

Tax evasion is studied by researchers from multiple disciplines and with different perspectives. As will be discussed further in the literature review, which is the next section of the paper, the scholarship on tax evasion is exceedingly diverse and includes both theoretical and practical orientations with little observable convergence of the many research streams at this point in time. This research effort is one of a tiny number which approach tax evasion from an ethical viewpoint. This is a necessary perspective because the psychologists, economists, and legal experts who build models and attempt to make assist in the development of tax policy will be limited in the contribution they can make if they and tax policy makers are not familiar with the ethical reasoning of individuals who make the choice to evade or not evade the individual income tax. Our research is also valuable because it seeks to examine an understudied but unique and increasingly important segment of Americans, Hispanics 
The remainder of the paper is organized as follows. The next section reviews the relevant literature. Examples of tax evasion research from different research streams are identified. The bulk of the literature review provides a more lengthy discussion of the ethics based research which is the research stream, which includes our paper. Data selection and methodology are described in the third section. The institution where the data was collected is named and some descriptive statistics are provided. Also the hypotheses are enumerated with the motivation for their inclusion. The fourth section reviews the results of the study and this section provides analysis and interpretations of the empirical findings. The fifth and final section concludes the research discussion and it highlights the contribution of the paper and suggests possibilities for further research. The survey instrument is included as an attachment.

\section{LITERATURE REVIEW}

Tax evasion scholarly research has been generated by accountants, economists, lawyers, and psychologists. Eric Posner (2000) is a law professor who writes from a legal perspective and an economic perspective. He notes that the bulk of taxpayer comply with the tax law has and thus seemingly contradict the standard economic model of law enforcement, which holds that people violate the law if the benefit exceeds the expected sanction. Although Posner does not then proceed to approach the issue from an ethical perspective, we argue that his observation motivates our approach which is to research ethical reasoning. Posner (2000) comments that the literature on tax evasion has not converged methodology wise and that all the ideas offered in the literature do not cohere. Slemrod (2007) is an economist who has reviewed the economics of tax evasion considering the public policy economics literature, and the models and tests and models of the economics-based positive theory of tax evasion. Slemrod has very significantly contributed to the public policy research stream through his work as Director of the Office of Tax Policy Research, at the University of Michigan Business School. Allingham and Sandmo (1972) developed the behavioral economic model which dominates the model building economic literature, although one is reminded that Posner observes that this literature seemingly under predicts the extant level of tax compliance, suggesting that an improved understanding of the ethical choices of individuals might enhance the current state of the art in tax compliance/tax evasion model building .

Psychologists such as Kirchler, Hoelzl, and Wahl (2008) also contribute to the literature of behavioral model building with research that adds the notion of social norms to the more traditional base of selfcentered economic type model building assumptions. One could imagine such social norms model building eventually linking directly to the ethical reasoning literature which we pursue. The remainder of this literature review is a discussion of the ethical reasoning tax evasion literature, Although many previous studies have investigated tax compliance, very few have examined tax compliance, or rather noncompliance, primarily from the perspective of ethics.

The ethics of tax evasion can be examined from a number of perspectives. Some of these are of a religious nature while others are more secular and philosophical. One approach is to examine the relationship of the individual to the state. Another is to review the relationship between the individual and the taxpaying community or some subset thereof. A third perspective is to observe the relationship of the individual to God. Martin Crowe (1944) examined the literature using all of these approaches in his doctoral thesis, The Moral Obligation of Paying Just Taxes. He reviewed the theological and philosophical debate that had been going on, mostly within the Catholic Church, over the previous 500 years.

One of the most comprehensive analyses on tax evasion from a philosophical perspective was a doctoral thesis written by Martin Crowe in 1944. The Journal of Accounting, Ethics \& Public Policy published a series of articles on tax evasion from various religious, secular and philosophical perspectives in 1998 and 1999. Most of those articles were also published in an edited book (McGee, 1998a). Since the publication of that book a few other articles have addressed the issue of tax evasion from an ethical perspective. 
The ethics of tax evasion can be examined from a number of perspectives. Some of these are of a religious nature while others are more secular and philosophical. One approach is to examine the relationship of the individual to the state. Another is the relationship between the individual and the taxpaying community or some subset thereof. A third is the relationship of the individual to God. Martin Crowe (1944) examined the literature on these approaches, which are the three main approaches that have been taken in the literature over the past five centuries.

One empirical study on the ethics of tax evasion was conducted by Nylén (1998), who distributed a survey soliciting the views of Swedish chief executive officers (CEOs). McGee (1998e) commented on this study. A study by Reckers, Sanders and Roark (1994) presented participants with a case study and asked them whether they would be willing to evade taxes. Englebrecht et al (1998) did a study involving 199 subjects who replied to 29 ethical orientation questions, some of which had to do with tax evasion. Inglehart et al (2004) conducted a large survey of more than 200,000 people in more than 80 countries that asked more than one hundred questions, one of which was about tax evasion. McGee and Tyler (2007) used the Inglehart data to examine the views on tax evasion of 33 countries.

Although many studies investigated issues about tax compliance, very few have examined tax or levies compliance, or rather noncompliance, primarily from the perspective of ethics. A significant number of studies on tax evasion look at the issue from the perspective of public finance or economics, with ethical issues mentioned briefly, if at all. The most comprehensive twentieth century work on the ethics of tax evasion was a doctoral thesis written by Martin Crowe (1944), titled The Moral Obligation of Paying Just Taxes. This thesis reviewed the theological and philosophical debate that had been going on, mostly within the Catholic Church, over the previous 500 years. Some of the debate took place in the Latin language. Crowe introduced this debate to an English language readership. A more recent doctoral dissertation on the topic was written by Torgler (2003), who discussed tax evasion from the perspective of public finance but also touched on some psychological and philosophical aspects of the issue. Alfonso Morales (1998) examined the views of Mexican immigrant street vendors and found that their loyalty to their families exceeded their loyalty to the government.

There have been a few studies that focus on tax evasion in a particular country. Ethics are sometimes discussed but, more often than not, the focus of the discussion is on government corruption and the reasons why the citizenry does not feel any moral duty to pay taxes to such a government. Ballas and Tsoukas (1998) discuss the situation in Greece. Smatrakalev (1998) discusses the Bulgarian case. Vaguine (1998) discusses Russia, as do Preobragenskaya and McGee (2004) to a lesser extent. A study of tax evasion in Armenia (McGee, 1999b) found the two main reasons for evasion to be the lack of a mechanism in place to collect taxes and the widespread opinion that the government does not deserve a portion of a worker's income.

A number of articles have been written from various religious perspectives. Cohn (1998) and Tamari (1998) discuss the Jewish literature on tax evasion and on ethics in general. Much of this literature is in Hebrew or a language other than English. McGee (1998d, 1999a) commented on these two articles from a secular perspective.

Several articles have been written on the ethics of tax evasion from various Christian viewpoints. Gronbacher (1998) addresses the issue from the perspectives of Catholic social thought and classical liberalism. Schansberg (1998) looks at the Biblical literature for guidance. Pennock (1998) discusses just war theory in connection with the moral obligation to pay just taxes, and not to pay unjust or immoral taxes. Smith and Kimball (1998) provide a Mormon perspective. McGee (1998c, 1999a) commented on the various Christian views from a secular perspective. 
The Christian Bible discusses tax evasion and the duty of the citizenry to support the government in several places. Schansberg (1998) and McGee (1994, 1998a) discuss the biblical literature on this point. When Jesus is asked whether people should pay taxes to Caesar, Jesus replied that we should give to Caesar the things that are Caesar's and give to God the things that are God's (Matthew 22:17, 21). But Jesus did not elaborate on the point. He did not say what we are obligated to give to the government or whether that obligation has limits. There are passages in the Bible that may be interpreted to take an absolutist position. For example, Romans 13, 1-2 is read by some to support the Divine Right of Kings.

A few other religious views are also addressed in the literature. Murtuza and Ghazanfar (1998) discuss the ethics of tax evasion from the Muslim perspective. McGee (1998b, 1999a) comments on their article and also discusses the ethics of tax evasion under Islam citing Islamic business ethics literature (McGee, 1997). DeMoville (1998) discusses the Baha'i perspective and cites the relevant literature to buttress his arguments. McGee (1999a) commented on the DeMoville article. McGee (2004) discusses these articles in a book from a philosophical perspective.

Some empirical studies have been conducted that solicit views on the ethics of tax evasion. McGee and Cohn (2008) surveyed the views of Orthodox Jews. The views of international business academics (McGee, 2005a) and various groups in Romania (McGee, 2005b), Thailand (McGee, 2006), Poland (McGee \& Bernal, 2006), Hong Kong (McGee, Ho \& Li, 2008) and China (McGee \& Noronha, 2008) have used survey instruments similar to the one used in this study. The present study replicates these studies but samples a predominantly Hispanic population, which has not been done before. Garcia (1997) has discussed personal ethics and moral reasoning from the viewpoint of American Hispanics. He states that the moral understanding and ways of American Hispanics are closely tied to their membership in well-defined ethnic groups. Hispanic morality, Garcia continues, "is influenced as much by the positive and negative elements of our Hispanic culture as by the positive and negative experiences we must respond to within Anglo Saxon culture." Given the uniqueness and importance of Hispanics in America we believe our research makes an important contribution to developing a complete understanding of the ethics of tax evasion in contemporary America.

\section{DATA AND METHODOLOGY}

The survey was distributed to graduate and undergraduate accounting and business students at Texas A\&M International University in Laredo, Texas. Three hundred nineteen (319) usable responses were collected. Data were compiled and examined based on gender, student status, major, ethnicity, residence and religion. The vast majority of students were Hispanic.

In testing the assumptions of the research, the authors obtained the overall descriptive characteristics of the variables for the original data. However, different procedures have applied to categorical variables (status, major, gender, age, residence, ethnicity and religion) versus continuous variables (Survey questions 1-18). Table 5 contains the expanded statistical output. The sample characteristics suggest (Table 1) that the dominant majority of respondents were undergraduate students $(84 \%)$ of Hispanic ethnic background (88\%), residing in the USA (88\%), aged under $25(69 \%)$ and were Catholics by their religious affiliation (78\%). Gender differentiation was somewhat evenly split with males standing at $47 \%$ and females at $53 \%$, while the area of concentration has been divided in the following order: business including economics $46 \%$, accounting $38 \%$, law $5 \%$ and all others. Detailed frequency tables (Tables 6-8) for original data are shown below.

After carefully evaluating descriptive characteristics of the original data, the authors decided to focus on the categorical variable representing only the Hispanic segment of the population $(88.2 \%$ of the original data). Furthermore, it became evident that categorical variables of "Status", "Religion" and "Residence" appeared to be skewed in one or the other direction. For example, the sample consisted of 77.5 percent of 
Catholics, with the remaining 22.5 percent spread among four other categories. Therefore, the authors decided to limit the use of their statistical value for further consideration. The main ethnic group was Hispanic (88.2\%), with the remaining 11.8 percent distributed over four other categories. Thus, a comparison based on religion or ethnicity would not be worthwhile because of the small sample sizes for non-Catholics and non-Hispanics.

Table 1: Total Sample Demographic Data

\begin{tabular}{|c|c|c|c|}
\hline STATUS & $\%$ & GENDER & $\%$ \\
\hline GRADUATE STUDENT & 13.2 & MALE & 46.6 \\
\hline UNDERGRADUATE STUDENT & 84.3 & FEMALE & 53.4 \\
\hline \multirow[t]{2}{*}{ OTHERS } & 2.5 & & 100 \\
\hline & 100 & & \\
\hline MAJOR & $\%$ & AGE & $\%$ \\
\hline ACCOUNTING & 38.3 & UNDER 25 & 68.6 \\
\hline BUSINESS-ECONOMICS & 45.7 & $25-40$ & 25.8 \\
\hline THEOLOGY-RELIGIOUS STUDIES & 0.6 & OVER 40 & 3.8 \\
\hline LAW & 4.5 & N/A & 1.7 \\
\hline \multirow[t]{2}{*}{ OTHER } & 10.9 & & 100 \\
\hline & 100 & & \\
\hline RESIDENCE & $\%$ & ETHNICITY & $\%$ \\
\hline$\overline{\mathrm{MEXICO}}$ & 11.8 & $\overline{\text { NON-HISPANIC WHITE }}$ & 6.5 \\
\hline \multirow[t]{2}{*}{ USA } & 88.2 & HISPANIC & 88.2 \\
\hline & 100 & AFRICAN-AMERICAN & 2.6 \\
\hline RELIGION & $\%$ & ASIAN & 2.3 \\
\hline CATHOLIC & 77.5 & OTHERS & 0.3 \\
\hline OTHER CHRISTIAN & 17 & & 100 \\
\hline JEWISH & 0.3 & & \\
\hline NONE-ATHEIST-AGNOSTIC & 0.3 & & \\
\hline \multirow[t]{2}{*}{ OTHER } & 4.8 & & \\
\hline & 100 & & \\
\hline
\end{tabular}

The table lists the details for the various demographic factors, which include student status, academic major, residence, religion, gender, age and ethnicity. Figures listed are for the entire sample.

Table 2: Hispanic Sample Demographic Data

\begin{tabular}{ll}
\hline GENDER & \\
\hline Male & $43.0 \%$ \\
Female & $57.0 \%$ \\
& $100.0 \%$ \\
\hline MAJOR & \\
\hline Accounting & $38.7 \%$ \\
Business-Economics & $43.2 \%$ \\
Other & $18.1 \%$ \\
& $100.0 \%$ \\
\hline AGE & \\
\hline Under 25 & $63.8 \%$ \\
$25-40$ & $36.2 \%$ \\
& $100.0 \%$ \\
\hline
\end{tabular}

The table lists the details for the demographic factors for the Hispanic portion of the total sample that were analyzed, which include gender, academic major and age. Other demographic factors were not examined because the sample was too homogeneous to allow comparisons between groups.

The "Age" categorical variable has been compressed to only two levels "Under 25" and "Above 25". Table 2 represents descriptive statistics for the restricted population selected for this academic investigation.

Not much research has been done to analyze views on tax evasion from a Hispanic perspective. Thus, the present research helps to fill this gap in the literature. 


\section{Hypotheses}

\section{H-1: Hispanic students of both sexes have similar attitude toward different ethical aspects of tax evasion.}

This hypothesis is of interest because gender seems to be an important variable documented in some social science research. Ruegger and King (1992) note that their findings, "suggests that gender is a significant factor in the determination of ethical conduct and that females are more ethical than males in their perception of business ethical situations". This study surveyed students at the University of Southern Mississippi. On the other hand more recent research by Bageac, Furrer, and Reynaud (2010) using French and Romanian management students commented that. "Our results show that the relationship between gender and the perception of business ethics is ambiguous." The research cited in this paragraph did not look at American Hispanic students, and it is of interest whether or not American Hispanics are more similar to American students at the University of Southern Mississippi or to the European students evaluated by Bageac, Furrer, and Reynaud (2010).

H-2: Area of concentration (Major) does not influence the attitude of Hispanic students toward different ethical aspects of tax evasion.

This hypothesis looks at ethical differences according to major. McGee and Bose (2008) found that major was significant in a study of Australian students. This hypothesis is of interest because some other prior research has not found ethical differences according to major. While an area of concentration difference, if it exists, might be due to self-selection, training effects, a combi9nation of these causes, or any number of other causes as yet unidentified. Documentation would be important, especially if it can later be shown that it is due to training effects. This would suggest that at least under some circumstances training could generate improved moral outcomes.

H-3: Age differentiation does not influence the attitude of Hispanic students toward different ethical aspects of tax evasion.

Previous ethical research on ethics has sometimes found age to be predictor of ethical decision making, and sometime not. Glover, Bumpus, Logan and Ciesta (1997) found that, "Age was not a predictor of ethical decision making. On the other hand, Babakus, Cornwall, Mitchell, and Schlegelmilch (2004) found that, "younger respondents tend to view unethical behaviour as more acceptable." The first study cited looked at Americans, the second study looked at six nationalities, including Americans. Given the divergent results, research focused on the ethics of Hispanic Americans is of interest because it is a new group to study and because earlier results seem to differ.

H-4: Hispanic students of both sexes and of all areas of concentration have similar attitude toward different ethical aspects of tax evasion.

This hypothesis is important because the documentation of this interaction would be interesting, especially because prior research has sometimes found significance concerning area of concentration and also often detected significant gender difference. A significant interaction when Hispanics are studied would be an important contribution.

H-5: Hispanic students of both sexes and of all ages have similar attitude toward different ethical aspects of tax evasion.

This hypothesis is of interest because, based on prior research, this interaction gender is often, but not always significant, and age is often significant with women often detected as more ethical. 
H-6: Hispanic students of all areas of concentration and of all ages have similar attitude toward different ethical aspects of tax evasion.

This hypothesis is important to consider because although both age and are of concentration are sometimes important when other ethnic groups have been studied. Significance in this interaction would indicate a previously undetected and unanticipated interaction relationship.

H-7: Hispanic students of both sexes, of all ages and of all areas of concentration have a similar attitude toward different ethical aspects of tax evasion.

This triple interaction is worthy of inclusion so that all interactions are evaluated. At this pint no existing theory is available that suggests a likelihood of significance of this triple interaction.

A three-way Multivariate Analysis of Variance (MANOVA) was conducted to examine how Hispanic students' attitude toward different ethical aspects of tax evasion (total 18) differed with student characteristics (gender, age and major) using the GLM analysis. A multivariate approach was chosen in order to control the Type I error and to detect combined differences that may not be evident from univariate tests (Hair, Anderson, Tatham \& Black, 1995). Multivariate analysis of variance (MANOVA) analysis is an appropriate tool for similar scenarios where more than one dependent variable was identified. Furthermore, these dependent variables might indirectly influence each other since they all identify perceived conditions for tax evasion. MANOVA analysis also helps to overcome issues related to several dependant variables closely measuring the same outcome aspects. Therefore, MANOVA is the most suitable statistical tool, since it compares the groups and identifies whether the mean differences between the groups on the combination of dependent variables are likely to have occurred by chance.

However, before we proceeded with the MANOVA analysis, it was prudent to test whether our data conform to the following assumptions: Sample Size, Normality, Outliners, Linearity, Homogeneity of Regression, Multicollinearity and singularity and Homogeneity of variance-covariance matrices. The Bartlett's test of sphericity had a significance level at $0.001(\chi 2=4026.992, \mathrm{df}=210, \mathrm{p}<0.05)$, satisfying the necessary requirement of intercorrelation to justify MANOVA. An expanded table for Bartlett's Test of sphericity and Kaiser-Meyer-Olkin measure of Sampling Adequacy can be seen in Table 7.

The Pillai's Trace was chosen for significance testing, because it is more robust (Hair et al, 1995, p. 278). The multivariate tests of the three-way M ANOVA were first performed, followed by univariate tests of each measure of tax evasion ethics. Because relatively small sample sizes such as the one used here tend to make very small effects statistically significant, the alpha level for significance was set at the $p<.05$ level. Spearman's correlation coefficients were used to analyze the direction and the strength of the relationship between different variables. Parametric tests (independent samples t-test and ANOVA) were performed to examine differences in scores, for each attitude-based utility measures, as a result of various socio-demographic and other factors such as status, major, age, gender, education, country of residence, ethnicity, and religion and multiplelinear regression analysis was performed to determine the most significant predictors. Analysis of Variances (ANOVA) was chosen since it provides a more efficient method for analyzing data of relatively smaller population which involves several categorical variables.

\section{RESULTS}

Academic major was the only demographic variable where significant differences in opinion were found. For some of the 18 arguments justifying tax evasion, accounting students were significantly more averse to tax evasion than were business and economics majors. Some arguments justifying tax evasion were stronger than others. The strongest arguments for evading taxes were in cases where the government engaged in human rights abuses. Other strong arguments were in cases where the tax system was 
perceived as unfair, where tax rates were too high, where government officials were corrupt or where tax funds were not spent wisely. Table 3 shows the ranking of the 18 arguments that were included in the survey instrument.

Table 3: Ranking of Arguments $(1=$ strongly agree; 7 = strongly disagree $)$

\begin{tabular}{|c|c|c|c|c|c|}
\hline Rank & $\begin{array}{c}\text { Statement } \\
\text { number }\end{array}$ & Statement & $\mathbf{N}$ & Mean & S.D. \\
\hline 1 & 16 & $\begin{array}{l}\text { Tax evasion would be ethical if I were a victim of an oppressive regime or } \\
\text { dictatorship similar to that in Stalinist Russia or Nazi Germany. }\end{array}$ & 316 & 4.76 & 2.306 \\
\hline 2 & 3 & Tax evasion is ethical if the tax system is unfair. & 319 & 4.86 & 2.185 \\
\hline 3 & 18 & $\begin{array}{l}\text { Tax evasion is ethical if the government imprisons people for their political } \\
\text { opinions. }\end{array}$ & 317 & 4.91 & 2.315 \\
\hline 4 & 17 & $\begin{array}{l}\text { Tax evasion is ethical if the government discriminates against me because of } \\
\text { my religion, race or ethnic background. }\end{array}$ & 316 & 4.96 & 2.297 \\
\hline 5 & 11 & $\begin{array}{l}\text { Tax evasion is ethical if a significant portion of the money collected winds } \\
\text { up in the pockets of corrupt politicians or their families and friends. }\end{array}$ & 316 & 5.00 & 2.265 \\
\hline 6 & 4 & Tax evasion is ethical if a large portion of the money collected is wasted. & 316 & 5.06 & 2.023 \\
\hline 7 & 14 & Tax evasion is ethical if I can't afford to pay. & 316 & 5.24 & 2.059 \\
\hline 8 & 6 & $\begin{array}{l}\text { Tax evasion is ethical if a large portion of the money collected is spent on } \\
\text { projects that I morally disapprove of. }\end{array}$ & 316 & 5.26 & 1.988 \\
\hline 9 & 1 & Tax evasion is ethical if tax rates are too high. & 316 & 5.44 & 1.902 \\
\hline 10 & 13 & $\begin{array}{l}\text { Tax evasion is ethical if some of the proceeds go to support a war that I } \\
\text { consider to be unjust. }\end{array}$ & 316 & 5.47 & 1.939 \\
\hline 11 & 7 & $\begin{array}{l}\text { Tax evasion is ethical even if a large portion of the money collected is spent } \\
\text { on worthy projects. }\end{array}$ & 316 & 5.63 & 1.917 \\
\hline 12 & 8 & $\begin{array}{l}\text { Tax evasion is ethical if a large portion of the money collected is spent on } \\
\text { projects that do not benefit me. }\end{array}$ & 316 & 5.64 & 1.876 \\
\hline 13 & 5 & Tax evasion is ethical even if most of the money collected is spent wisely. & 316 & 5.71 & 1.860 \\
\hline 14 & 9 & $\begin{array}{l}\text { Tax evasion is ethical even if a large portion of the money collected is spent } \\
\text { on projects that do benefit me. }\end{array}$ & 316 & 5.76 & 1.758 \\
\hline 15 & 15 & $\begin{array}{l}\text { Tax evasion is ethical even if it means that if I pay less, others will have to } \\
\text { pay more. }\end{array}$ & 316 & 5.79 & 1.705 \\
\hline 16 & 10 & Tax evasion is ethical if everyone is doing it. & 316 & 5.80 & 1.842 \\
\hline 17 & 2 & $\begin{array}{l}\text { Tax evasion is ethical even if tax rates are not too high because the } \\
\text { government is not entitled to take as much as it is taking from me. }\end{array}$ & 316 & 5.81 & 1.616 \\
\hline \multirow[t]{5}{*}{18} & 12 & Tax evasion is ethical if the probability of getting caught is low. & 316 & 5.94 & 1.712 \\
\hline & & Overall Mean & 5.39 & & \\
\hline & & Median & 5.46 & & \\
\hline & & Range & $4.76-5.94$ & & \\
\hline & & Cronbach's Alpha & .950 & & \\
\hline
\end{tabular}

The table shows the ranking for each argument as well as the statement number, the argument, the mean and the standard deviation. The bottom of the table lists the overall mean, the median, range and Cronbach's Alpha.

Factor analysis identified three groupings of responses. The group of arguments thought to provide the strongest justification for tax evasion all had to do with human rights abuses. The argument thought to be the strongest justification for tax evasion was the case of someone who lived under a dictatorship or other 
oppressive regime. The other two human rights abuses statements involved the case of government imprisoning people for their political opinions and the case where government discriminates against people on the basis of religion, race or ethnic background.

The second group of arguments, which had the second highest grouping of mean scores, consisted of arguments involving fairness or morality. The strongest argument in this category was the case where the tax system was perceived as unfair. This response also correlated highly with the human rights arguments.

Other statements in the fairness and morality category included arguments to justify tax evasion in cases where tax funds wind up in the pockets of corrupt politicians or their friends and family; cases where tax funds are wasted; where there is inability to pay; where tax funds are spent on projects the taxpayer disapproves of; where tax rates are too high; and where tax funds are used to support an unjust war.

The category that had the least support for tax evasion included cases involving duty to the state. The argument that tax evasion is acceptable if the probability of getting caught is low was the least persuasive statement.

Other studies that used a similar survey instrument found similar relationships and rankings, which might lead one to conclude that the views on tax evasion of Mexicans living in the United States might not be too different from the views of Orthodox Jews (McGee \& Cohn, 2008), Romanians (McGee, 2005b) or Poles (McGee \& Bernal, 2006). However, such a conclusion would be premature. Although the rankings and relationships are similar, a comparison of mean scores found that the relative seriousness of tax evasion differed among studies.

The group most opposed to tax evasion in general, based on the overall mean score, was Orthodox Jews (McGee \& Cohn, 2008: Mean = 5.57), followed by Mexicans living in Texas (Current study: Mean = 5.39). The group least opposed to tax evasion was the Romanian group (McGee, 2005b: Mean $=4.59$ ), followed by the Polish sample (McGee \& Bernal, 2006: Mean =4.7). Thus, while one might say that the ranking of the various arguments that have been used to justify tax evasion might be similar across cultures, it would not be accurate to say that opinions on the seriousness of tax evasion are constant across cultures.

The results of multivariate tests presented in Table 4 showed that only "Major" $(\mathrm{F}=1.843, \mathrm{p}<0.05)$ had a significant relation with all aspects of tax evasion, thus $\mathrm{H}-2$ is rejected $\mathrm{H}-1$ and $\mathrm{H}-3$ are not rejected.

Table 4: Results of the Three-way MANOVA Test

\begin{tabular}{llll}
\hline Source & Pillai's Trace & F value & p value \\
\hline GENDER & 0.092 & 1.228 & 0.24 \\
AGE & 0.053 & 0.679 & 0.83 \\
MAJOR & 0.262 & 1.843 & $.003^{*}$ \\
GENDER *AGE & 0.07 & .915 & .561 \\
GENDER*MAJOR & 0.223 & 1.534 & $.027^{* *}$ \\
AGE*MAJOR & 0.211 & 1.441 & 0.051 \\
GENDER*AGE*MAJOR & 0.197 & 1.333 & .099 \\
\hline
\end{tabular}

This table shows the Pillai's Trace, the F value and the p value for each demographic variable as well as for comparisons of two or three of the demographic variables. * Significant at 1-percent level. ** Significant at 5-percent level.

Two-way interactions were significant for "Gender X Major" $(\mathrm{F}=1.534, \mathrm{p}<.05)$ and marginally significant for "Age X Major" $(\mathrm{F}=1.441, \mathrm{p}=0.51)$. The three-way interaction of "Gender X Age $\mathrm{X}$ Major" was not significant $(\mathrm{F}=1.333, \mathrm{p}>0.05)$. and thus $\mathrm{H}-7$ was not rejected. 
Table 5 shows the statistics for the 18 statements and the demographic variables. Gender had the lowest frequency $(\mathrm{N}=294)$ among the demographic variables. Status with an N of 317 had the highest.

Table 5: Statements and Demographic Variables

\begin{tabular}{|c|c|c|c|c|c|c|c|c|}
\hline & $\begin{array}{c}\mathrm{N} \\
\text { Statistic }\end{array}$ & $\begin{array}{c}\text { Range } \\
\text { Statistic }\end{array}$ & $\begin{array}{c}\text { Minimum } \\
\text { Statistic }\end{array}$ & $\begin{array}{c}\text { Maximum } \\
\text { Statistic }\end{array}$ & $\begin{array}{c}\text { Mean } \\
\text { Statistic }\end{array}$ & Std. Error & $\begin{array}{c}\text { Std. } \\
\text { Deviation }\end{array}$ & $\begin{array}{l}\text { Variance } \\
\text { Statistic }\end{array}$ \\
\hline S1 & 319 & 6 & 1 & 7 & 5.44 & 0.107 & 1.912 & 3.655 \\
\hline $\mathrm{S} 2$ & 319 & 6 & 1 & 7 & 5.8 & 0.091 & 1.632 & 2.664 \\
\hline S3 & 319 & 6 & 1 & 7 & 4.85 & 0.122 & 2.186 & 4.778 \\
\hline S4 & 319 & 6 & 1 & 7 & 5.04 & 0.114 & 2.028 & 4.111 \\
\hline S5 & 318 & 6 & 1 & 7 & 5.71 & 0.104 & 1.855 & 3.442 \\
\hline S6 & 319 & 6 & 1 & 7 & 5.25 & 0.112 & 1.993 & 3.973 \\
\hline S7 & 319 & 6 & 1 & 7 & 5.62 & 0.108 & 1.927 & 3.715 \\
\hline $\mathrm{S} 8$ & 318 & 6 & 1 & 7 & 5.62 & 0.106 & 1.889 & 3.567 \\
\hline S9 & 319 & 6 & 1 & 7 & 5.75 & 0.099 & 1.772 & 3.14 \\
\hline S10 & 319 & 6 & 1 & 7 & 5.79 & 0.104 & 1.854 & 3.439 \\
\hline S11 & 319 & 6 & 1 & 7 & 4.97 & 0.127 & 2.276 & 5.182 \\
\hline $\mathrm{S} 12$ & 319 & 6 & 1 & 7 & 5.93 & 0.097 & 1.727 & 2.983 \\
\hline $\mathrm{S} 13$ & 319 & 6 & 1 & 7 & 5.46 & 0.109 & 1.947 & 3.79 \\
\hline S14 & 319 & 6 & 1 & 7 & 5.24 & 0.116 & 2.068 & 4.276 \\
\hline S15 & 318 & 6 & 1 & 7 & 5.78 & 0.097 & 1.723 & 2.967 \\
\hline S16 & 319 & 6 & 1 & 7 & 4.76 & 0.129 & 2.31 & 5.335 \\
\hline S17 & 319 & 6 & 1 & 7 & 4.96 & 0.129 & 2.299 & 5.287 \\
\hline S18 & 319 & 6 & 1 & 7 & 4.91 & 0.13 & 2.318 & 5.372 \\
\hline Status & 317 & 5 & 1 & 6 & 1.91 & 0.027 & 0.478 & 0.229 \\
\hline Major & 311 & 5 & 1 & 6 & 2.2 & 0.09 & 1.585 & 2.513 \\
\hline Gender & 294 & 1 & 1 & 2 & 1.53 & 0.029 & 0.5 & 0.25 \\
\hline Age & 287 & 3 & 1 & 4 & 1.39 & 0.038 & 0.648 & 0.42 \\
\hline Residence & 313 & 1 & 1 & 2 & 1.88 & 0.018 & 0.323 & 0.105 \\
\hline Ethnicity & 306 & 5 & 1 & 6 & 2.02 & 0.028 & 0.485 & 0.236 \\
\hline Religion & 311 & 5 & 1 & 6 & 1.43 & 0.064 & 1.122 & 1.259 \\
\hline
\end{tabular}

This table lists the sample size, range, mean, standard error, standard deviation and variance for each of the 18 statements as well as the demographic variables that were examined.

Table 6 shows the composition of the various demographic variables. There are more females (57\%) than males (43\%) Age data revealed that 36.2 per cent of the students were 25 years or older highlighting a large amount of non-traditional students. Accounting majors were 38.7 per cent of the students surveyed, with 43.2 percent of the students studying business - economics, with "others" at 19.1 per cent. Use of the KMO measure and the Bartlett's test confirmed the presence of an adequate sample.

The authors then performed respective univariate tests to determine the relations of the "Gender*Major" variables with each aspect of tax evasion. Table 7 shows the univariate tests results for gender and major for statements 4, 5, and 11. According to the outcomes of univariates tests, results are significant with respect to the statements of "Tax evasion is ethical if a large portion of the money collected is wasted" $(\mathrm{F}=3.364, \mathrm{p}<0.05)$ (Table 7) and "Tax evasion is ethical if a large portion of the money collected is spent wisely" $(\mathrm{F}=4.210, \mathrm{p}<0.05)$ (Table 7). There are significant differences between accounting majors and business-economics majors in their approach to those issues. 
Table 6: Demographic Variables

\begin{tabular}{|c|c|c|c|c|}
\hline & Frequency & Percent & Valid Percent & Cumulative Percent \\
\hline \multicolumn{5}{|l|}{ Gender } \\
\hline Valid Male & 108 & 39.9 & 43.0 & 43.0 \\
\hline Female & 143 & 52.8 & 57.0 & 100.0 \\
\hline Total & 251 & 92.6 & 100.0 & \\
\hline Missing/System & 20 & 7.4 & & \\
\hline Total & 271 & 100.0 & & \\
\hline \multicolumn{5}{|l|}{ Age } \\
\hline Under 25 & 173 & 63.8 & 63.8 & 63.8 \\
\hline 25 Or Older & 98 & 36.2 & 36.2 & 100.0 \\
\hline Total & 271 & 100.0 & 100.0 & \\
\hline \multicolumn{5}{|l|}{ Major } \\
\hline Accounting & 105 & 38.7 & 38.7 & 38.7 \\
\hline Business-Economics & 117 & 43.2 & 43.2 & 81.9 \\
\hline Others & 49 & 18.1 & 18.1 & 100.0 \\
\hline Total & 271 & 100.0 & 100.0 & \\
\hline \multicolumn{5}{|l|}{ Kmo And Bartlett's Test } \\
\hline \multicolumn{3}{|c|}{ Kaiser-Meyer-Olkin Measure of Sampling Adequacy } & 0.931 & \\
\hline \multirow[t]{3}{*}{ Bartlett's Test of Sphericity } & \multicolumn{2}{|c|}{ Approx. Chi-Square } & 4026.992 & \\
\hline & \multicolumn{2}{|l|}{ Df } & 210.000 & \\
\hline & \multicolumn{2}{|l|}{ Sig. } & $.000 *$ & \\
\hline
\end{tabular}

This table shows the sample size, percentages, valid percentages and cumulative percentages for the gender, age and major demographic variables, as well as the statistics for the KMO and Bartlett's Test.

* Significant at 5-percent level.

Table 7 - Multiple Comparisons/Univariate Test Results (Gender \& Major)

\begin{tabular}{|c|c|c|c|c|c|c|}
\hline \multirow[t]{2}{*}{ Major } & \multirow{2}{*}{ (J) Major } & \multirow{2}{*}{$\begin{array}{l}\text { Mean } \\
\text { Difference (I-J) }\end{array}$} & \multirow[t]{2}{*}{ Std. Error } & \multirow[t]{2}{*}{ Sig. } & \multicolumn{2}{|c|}{$95 \%$ Confidence Interval } \\
\hline & & & & & Lower Bound & Upper Bound \\
\hline \multicolumn{7}{|c|}{ S4: Tax evasion is ethical if a large portion of the money collected is wasted. } \\
\hline \multirow[t]{2}{*}{ Accounting } & Bus - Econ & 1.37 & .261 & $.000^{*}$ & .76 & 1.99 \\
\hline & OTHERS & .81 & .396 & .101 & -.12 & 1.75 \\
\hline \multirow[t]{2}{*}{ Bus - Econ } & Accounting & -1.37 & .261 & $.000^{*}$ & -1.99 & -.76 \\
\hline & Others & -.56 & .391 & .331 & -1.48 & .37 \\
\hline \multirow[t]{2}{*}{ Others } & Accounting & -.81 & .396 & .101 & -1.75 & .12 \\
\hline & Bus - Econ & .56 & .391 & .331 & -.37 & 1.48 \\
\hline \multicolumn{7}{|c|}{ S5: Tax evasion is ethical even if most of the money collected is spent wisely. } \\
\hline \multirow[t]{2}{*}{ Accounting } & Bus - Econ & .97 & .241 & $.000^{*}$ & .40 & 1.54 \\
\hline & Others & .43 & .364 & .470 & -.43 & 1.29 \\
\hline \multirow[t]{2}{*}{ Bus - Econ } & Accounting & -.97 & .241 & $.000^{*}$ & -1.54 & -.40 \\
\hline & Others & -.54 & .360 & .294 & -1.39 & .31 \\
\hline \multirow[t]{2}{*}{ Others } & Accounting & -.43 & 364 & 470 & -1.29 & 43 \\
\hline & BUS - ECON & .54 & .360 & .294 & -.31 & 1.39 \\
\hline \multicolumn{7}{|c|}{ S11: Tax evasion is ethical if a significant portion of the money collected winds up in the pockets of corrupt politicians or their families } \\
\hline \multirow[t]{2}{*}{ ACCOUNTING } & Bus - Econ & 1.13 & .306 & $.001^{*}$ & .41 & 1.85 \\
\hline & Others & .73 & .463 & .262 & -.37 & 1.82 \\
\hline \multirow[t]{2}{*}{ BUS - ECON } & Accounting & -1.13 & .306 & $.001^{*}$ & -1.85 & -.41 \\
\hline & Others & -.40 & 458 & 655 & -1.48 & 68 \\
\hline \multirow[t]{2}{*}{ OTHERS } & Accounting & -.73 & 463 & 262 & -1.82 & .37 \\
\hline & Bus-Econ & .40 & .458 & .655 & -.68 & 1.48 \\
\hline
\end{tabular}


Furthermore, the results are marginally significant for the statement "Tax evasion is ethical even if a large portion of the money collected is spent on projects that do benefit me" $(\mathrm{F}=2.946, \mathrm{p}=.055)$ (Table 7). To identify the nature of the differences between groups, the study performed a 2-way ANOVA treating the tax evasion statements mentioned above as dependent variables against "Major" and "Gender" status as independent variables.

Table 8 - Multiple Comparisons/Univariate Test Results (Age \& Major)

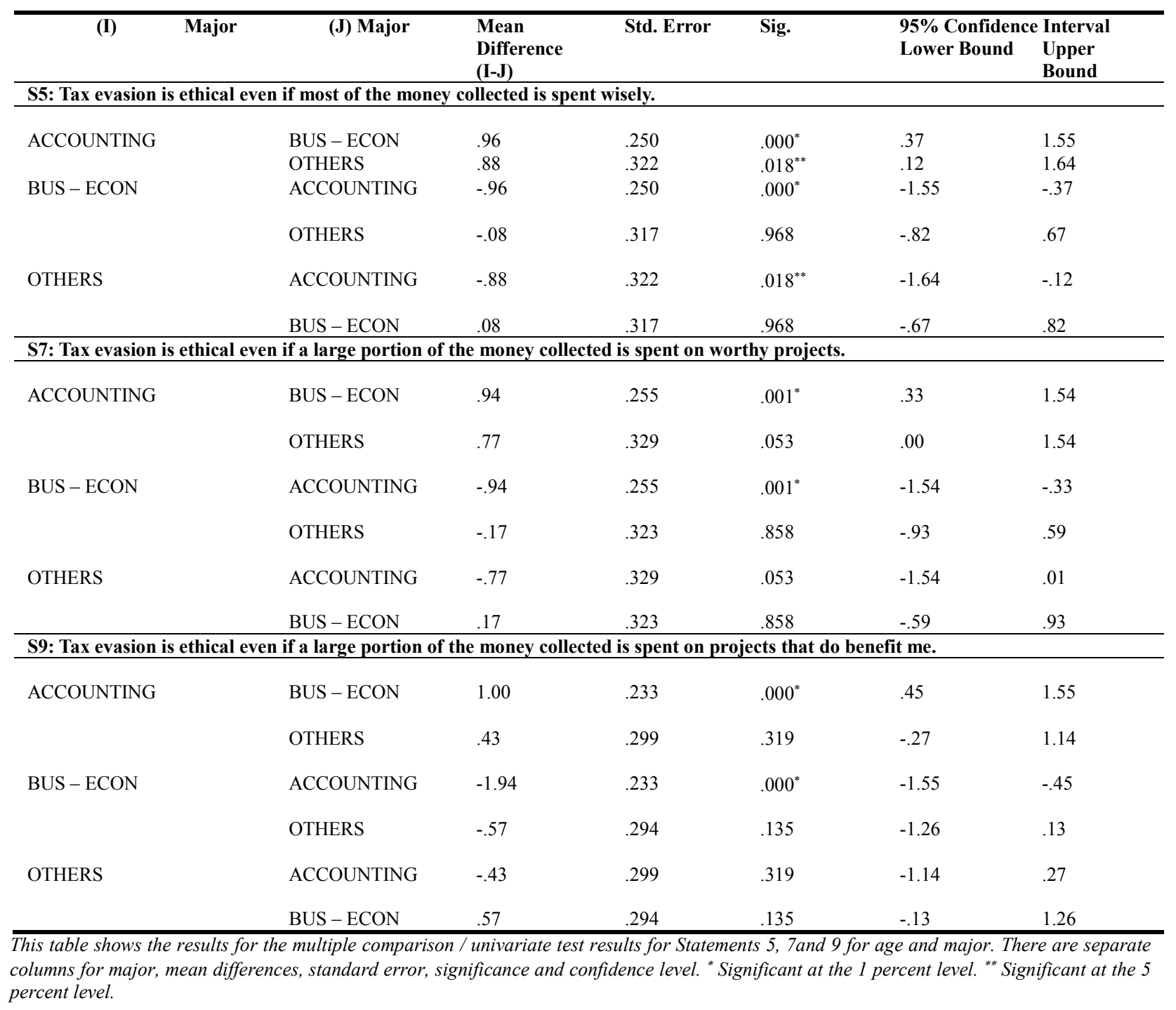

According to the results of Tukey's honest significance test (HSD) (Table 7) there are significant differences between accounting majors and business/economics majors with respect to both when tax evasion being ethical if money is wasted and money has been spent wisely. According to the table of multiple comparisons of mean differences, accounting students are less prone to tax evasion than their business major counterparts under those conditions. Furthermore, there are marginally significant differences $(\mathrm{p}<0.05)$ between accounting majors and business-economics majors in the perception of tax evasion being ethical if a significant portion the money collected winds up in the pockets of corrupt politicians or their families and friends. 
As it was mentioned above, according to the results of multivariate Tests (Pillai's trace: $\mathrm{F}=1.441, \mathrm{p}=$ 0.51) there are some marginally significant results with respect to Age X Major. Table 8 shows the comparisons and univariate results for age and major for statements 5, 7 and 9. According to the outcome of univariate tests results are significant with the respect to "Tax evasion is ethical if a large portion of the money collected is spent wisely" $(\mathrm{F}=3.175, \mathrm{p}<0.05)$ (Table 7), "Tax evasion is ethical if a large portion of the money collected is spent on worthy projects" $(\mathrm{F}=3.444, \mathrm{p}<0.05)$ (Table 7$)$ and "Tax evasion is ethical if a large portion of the money collected is spent on projects that do benefit me" $(\mathrm{F}=4.961, \mathrm{p}<$ 0.05) (Table 7). According to the results of 2-way ANOVA (tax evasion statements mentioned above as dependent variables against "Major" and "Age" status as independent variables), in Hispanic population, accounting major students are more cautious than their business-economics counterparts when it comes to specific tax evasion issues outlined above.

A number of studies have been done on gender ethics. Some studies found that women were more ethical than men (Akaah, 1989; Betz et al., 1989; Glover et al., 1997), while other studies found no significant differences between male and female views on ethical issues (Babakus et al., 2004; Dubinsky \& Levy, 1985; Kidwell et al., 1987). A few studies have found men to be more ethical than women (Barnett \& Karson, 1987; Weeks et al., 1999). In cases where women are found to be more ethical, possible explanations that have been given are that women are taught to respect authority and that they are more caring and nurturing, and are thus more sensitive to harming others. In cases where there is no statistically significant difference between men and women, one reason that has been given is that, as women become more equal with men, their attitudes become more like those of men. If those reasons are valid, one might reasonably conclude that Mexican women have been sufficiently liberated to have views on tax evasion that are similar to those of Mexican men. The literature is unclear on why men might be more ethical than women.

A philosophical word of caution needs to be given here, however. If one states that women are more opposed to tax evasion, it is not the same as saying that women are more ethical than men. In order to arrive at that conclusion, one must begin with the underlying premise that tax evasion is unethical, which may or may not be the case. For example, a strong case could be made that it is not unethical for Jews living in Nazi Germany to evade taxes. There is also a great deal of support for the argument that tax evasion is not unethical if the government engages in human rights abuses or if the government is engaged in an unjust war. In the present study, men's and women's views on tax evasion were not significantly different, but that is not quite the same as saying that men and women are equally ethical when it comes to tax evasion. All that can be said is that their views on tax evasion do not differ significantly.

Where gender differences have been tested in tax evasion studies the results are mixed. Women were found to be significantly more opposed to tax evasion in studies of Orthodox Jews (McGee \& Cohn, 2008) and international business academics (McGee, 2005a), whereas men were found to be significantly more opposed to tax evasion in a study of Romanian business students (McGee, 2005b). Differences between male and female views were found to be statistically insignificant in studies of Polish (McGee \& Bernal, 2006) and Chinese (McGee \& Noronha, 2008) students.

Ethical studies that examined age as a variable have generally found that people become more ethical with age, or that people tend to have more respect for authority as they get older (Barnett \& Karson, 1987, 1989; Longenecker et al., 1989; Harris, 1990; Kelley et al., 1990; Ruegger \& King, 1992). However, Marta et al. (2004) found that age does not affect views on ethics in the Middle East.

The present study found that ethical views on tax evasion do not differ significantly based on age. This finding seemingly contradicts the finds of the studies cited above. However, the sample in the present study consisted of people who were mostly young, so age comparisons had to be made between two 
groups that were both mostly young. Thus, one can conclude that age is not a significant demographic in cases where young students are sampled.

The present study found that accounting majors are sometimes significantly more opposed to tax evasion than are business and economics students, depending on the issue. This finding is not surprising, since accounting students are taught how to comply with the tax laws and are taught to follow accounting and tax rules in their various courses. However, a study of Estonian students found that the difference between accounting and business and economic student mean scores was not significant (McGee, Alver \& Alver, 2008). Thus, it cannot be stated categorically that accounting students are always more opposed to tax evasion than business and economics students.

A few other tax evasion studies have included academic major as a demographic variable. An Armenian study (McGee \& Maranjyan, 2008) found that business and economics students were more opposed to tax evasion than were theology students. The reason given for this surprising result was that theology is a business in Armenia.

An Australian study (McGee \& Bose, 2009) found that business and economics students were least opposed to tax evasion; seminary students were most opposed; Business and economics students were significantly less opposed to tax evasion than were philosophy, accounting, health services and seminary students. Accounting majors were significantly more opposed to tax evasion than were business \& economics, and information technology students and were significantly less opposed to tax evasion than were seminary and health services students.

\section{CONCLUDING COMMENTS}

To better deal with tax evasion we need to understand the root causes of tax evasion and the reasons why people evade taxes. The goal of this study was to determine the strength of various arguments that have been used to justify tax evasion in the past and to determine whether results differ based on certain demographic variables. It was found that some arguments that have been used historically to justify tax evasion are stronger than others and that academic major is correlated with views on tax evasion in some cases.

Data was gathered by distributing a survey to Hispanic business students at a university in South Texas. The survey instrument contained 18 statements that had been used to justify tax evasion in the past. A number of statistical tests were conducted to determine which arguments justifying tax evasion were the strongest. The statements were then ranked by mean score. Further statistical tests were made to determine whether gender, age or academic major made a difference in opinion.

It was found that the strongest arguments for justifying tax evasion have to do with government abuses and corruption and the belief that the tax system is unfair. From a policy perspective, one might conclude that the way to minimize tax evasion would be to have less government abuses and corruption and more fairness and equity in the tax system.

Gender, age and academic major were examined to determine whether these demographic variables contained significant differences between groups. The study found that only academic major had significant differences. Accounting majors were in some cases significantly more opposed to tax evasion than business and economics students. However, in other cases the differences were not significant.

The Hispanic component of the American population is growing rapidly and it is expected to continue its rapid growth indefinitely. Our research finds that Hispanic accounting majors are more ethical in regards to tax evasion than other business and economics majors. More research is needed to determine if this is 
because of the unique and specific training accounting majors get or if it is because more ethical persons self select to become accounting majors. For example, the risk-reward ratio is different for a paid tax return preparer who must sign a return than the actual taxpayer who may reap the full economic benefit of successful tax evasion. Hence, it is important to know if there is a lack of sufficient financial motivation for accounting majors to evade taxes or if there is different ethical reasoning involved that is based on education or self selection.

Future research could explore the willingness of non-Hispanic groups in the U. S. to evade taxes and also the reasoning behind their decision to evade taxes to determine whether significant differences exist in their ethical attitudes toward tax evasion. Comparisons could be made between Hispanic and nonHispanic groups to see if there is any difference in viewpoint based on ethnicity.

The present study has some limitations. Since students were surveyed, there is always a question of whether the results of the study can be generalizable to the total population. Perhaps students think differently than their parents. Also, since students are generally younger than the general population, student surveys do not include the views of older people. In addition, since the sample population consisted of individuals who are better educated than a major segment of the general population, there is always the possibility that people who have different educational levels might have different opinions on the ethics of tax evasion. These limitations are present in all student surveys. However, hundreds of studies have used student populations and it is an accepted methodology. A sample that included older people and nonstudents might have found different results. Such a study could serve as a logical expansion of the present study.

The Hispanics surveyed in the present study were from South Texas. Hispanics in this region of the United States are mostly of Mexican origin. It is likely that Hispanics from California, Arizona and New Mexico would have similar views on tax evasion, since Hispanics in those states also tend to be of Mexican background, but this assumption could be tested. Perhaps the Mexicans in these states have different attitudes toward tax evasion, but one may only assume a similar attitude until these samples are tested.

Another possible study would involve comparing Texas Hispanics of Mexican origin with Mexicans who live in Mexico. It is possible that living in the United States has caused Texas-based Mexicans to have opinions that differ from those of Mexicans still living in Mexico.

Another fertile ground for further research would be to compare Hispanics who have different countries of origin. Most Hispanics who live in the Southwestern United States are of Mexican origin but many Hispanics who live in other states do not have their origins in Mexico. For example, the Hispanics who live in South Florida are predominantly of Cuban origin, although several other Latin American countries are also represented. Hispanics who live in the New York metropolitan area have roots in Puerto Rico, the Dominican Republic and other Latin American countries. It is entirely possible that the views of Hispanics in South Florida or New York might differ significantly from the Hispanics in the Southwestern United States, but their relative views have not yet been tested and compared. 


\section{APPENDIX}

\section{Appendix 1: Survey Instrument}

Instructions: Tax evasion is defined as the illegal nonpayment of a tax. Tax avoidance, on the other hand, occurs when someone finds a way to legally minimize or reduce taxes. Please answer the following questions dealing with the ethics of tax evasion. If you would like to receive a copy of the results of this survey, please send an e-mail to Arsen M. Djatej at arsen@tamiu.edu

Instrucciones: Jesús dijo que debíamos dar al César lo que es del César y a Dios lo que es de Dios, pero no entró en detalles con respecto a cuánto hay que darle al César. Conteste, por favor, las siguientes preguntas que tratan del aspecto ético de la evasión de Impuestos. Si ya contestó este cuestionario en otra clase, no vuelva a contestarlo. Si le interesaría recibir una copia del resultado de esta encuesta, escriba al Arsen M. Djatej at arsen@tamiu.edu solicitándola. Incluya su dirección electrónica en la carta.

The Ethics of Tax Evasion-La Ética De La Evasión De Impuestos

Please insert the appropriate number in the space provided for the following statements.

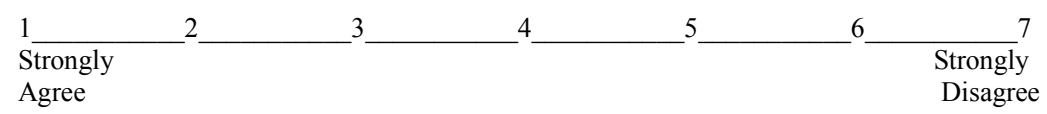

Escriba el número apropiado al lado de cada aseveración.

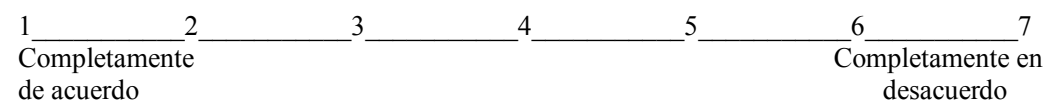

1.___ Tax evasion is ethical if tax rates are too high. La evasión de impuestos es ética si las tasas de impuestos son demasiado altas.

2. Tax evasion is ethical even if tax rates are not too high because the government is not entitled to take as much as it is taking from me. La evasión de impuestos es ética aunque las tasas de impuesto no sean muy elevadas.

3. Tax evasion is ethical if the tax system is unfair. La evasión de impuestos es ética si el sistema fiscal es injusto.

4. Tax evasion is ethical if a large portion of the money collected is wasted. La evasión de impuestos es ética si gran parte de los fondos recaudados se malgasta.

5. Tax evasion is ethical even if most of the money collected is spent wisely. La evasión de impuestos es ética aunque la mayor parte de los fondos recaudados sea usada de manera prudente.

6._Lax evasion is ethical if a large portion of the money collected is spent on projects that I morally disapprove of. La evasión de impuestos es ética si gran parte de los fondos recaudados se usa en proyectos con los cuales yo no estoy moralmente de acuerdo.

7. Tax evasion is ethical even if a large portion of the money collected is spent on worthy projects. La evasión de impuestos es ética aunque gran parte de los fondos recaudados se use en proyectos encomiables.

8. Tax evasion is ethical if a large portion of the money collected is spent on projects that do not benefit me. La evasión de impuestos es ética si gran parte de los fondos recaudados se usa en proyectos que no me benefician.

9. Tax evasion is ethical even if a large portion of the money collected is spent on projects that do benefit me. La evasión de impuestos es ética si gran parte de los fondos recaudados se usa en proyectos que me benefician.

10. Tax evasion is ethical if everyone is doing it. La evasión de impuestos es ética si todo el mundo participa en ella.

11. Tax evasion is ethical if a significant portion of the money collected winds up in the pockets of corrupt politicians or their families and friends. La evasión de impuestos es ética si gran parte de los fondos recaudados termina en los bolsillos de políticos corruptos o de sus familiares y amigos.

12. Tax evasion is ethical if the probability of getting caught is low. La evasión de impuestos es ética si hay pocas probabilidades de ser descubierto.

13. Tax evasion is ethical if some of the proceeds go to support a war that I consider to be unjust. La evasión de impuestos es ética si algunas de las ganancias se utilizan para respaldar una guerra que yo considero injusta.

14. Tax evasion is ethical if I can’t afford to pay. La evasión de impuestos es ética si yo no puedo pagar los impuestos.

15. Tax evasion is ethical even if it means that if I pay less, others will have to pay more. La evasión de impuestos es ética aunque implique que si yo pago menos otros tendrán que pagar más. 
16. Tax evasion would be ethical if I were a victim of an oppressive regime or dictatorship similar to that in Stalinist Russia or Nazi Germany. Considera usted que la evasion impositiva es etica cuando el gobierno es opresivo como en la Dictadura Stalinista en Rusia o en la Dictadura Nazi en Alemania.

17.__ Tax evasion is ethical if the government discriminates against me because of my religion, race or ethnic background. La evasión de impuestos es ética si sufro discriminación por parte del gobierno debido a mi religión, raza o grupo étnico.

18. Tax evasion is ethical if the government imprisons people for their political opinions. La evasión de impuestos es ética si el gobierno encarcela a las personas por sus puntos de vista políticos.

I am a(n): __ graduate student _ _ undergraduate student

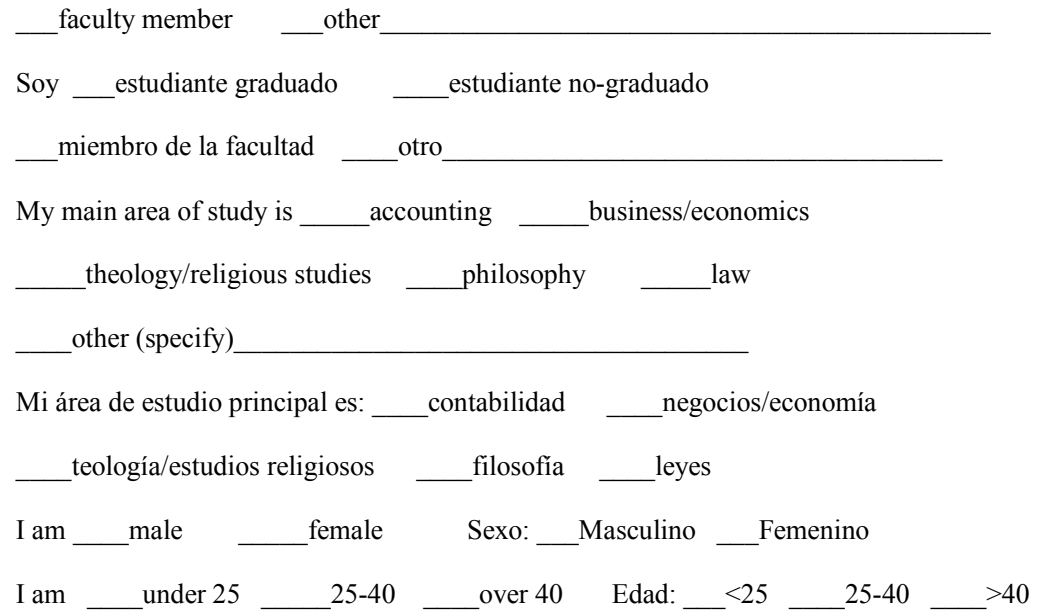

I currently reside/live/commute in(from) Mexico

Vivo en Mexico

I currently reside/live/commute in(from) USA

Vivo en EEUU

I live in Mexico but work in the USA

Vivo en Mexico y trabajo en EEUU

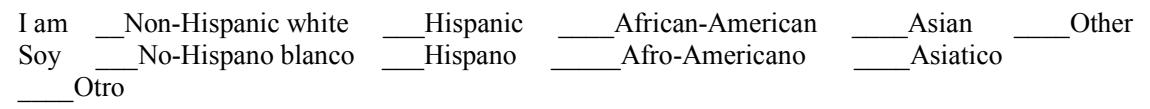

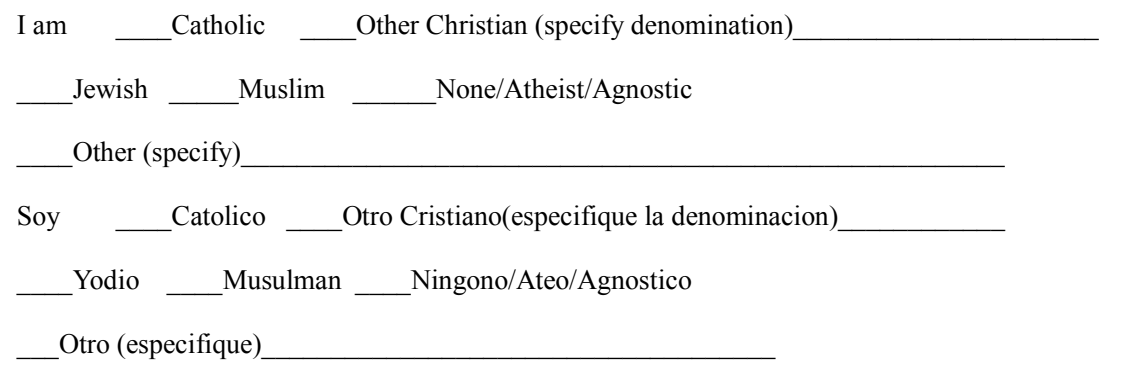

(Optional Comments) What are your views on the ethics of tax evasion? What determines whether tax evasion is ethical or unethical? You may use the back of this questionnaire if you need more space.

\section{REFERENCES}

Akaah, I. P. (1989). Differences in Research Ethics Judgments Between Male and Female Marketing Professionals. Journal of Business Ethics, 8(5), 375-381. 
Allingham, M. \& Sandmo, A., Income Tax Evasion: A Theoretical Analysis, Journal of Public Economics, 1(3/4), 323-338.

Alm, J. \& Torgler, B. (2004). Estimating the Determinants of Tax Morale. National Tax Association Tax Institute of America. Proceedings of the Annual Meeting. 269-274.

Babakus, E., Cornwell, T.B., Mitchell, V. \& Schlegelmilch, B. (2004). Reactions to Unethical Consumer Behavior across Six Countries. The Journal of Consumer Marketing, 21(4/5), 254-263.

Ballas, A. A. \& Tsoukas, H. (1998). Consequences of Distrust: The Vicious Circle of Tax Evasion in Greece, Journal of Accounting, Ethics \& Public Policy, 1(4), 572-596, reprinted in R. W. McGee (Ed.), The Ethics of Tax Evasion (pp. 284-304). Dumont, NJ: The Dumont Institute for Public Policy Research, 1998.

Barnett, J. H. \& Karson, M.J. (1987). Personal Values and Business Decisions: An Exploratory Investigation. Journal of Business Ethics, 6(5), 371-382.

Barnett, J. H. \& Karson, M.J. (1989). Managers, Values, and Executive Decisions: An Exploration of the Role of Gender, Career Stage, Organizational Level, Function, and the Importance of Ethics, Relationships and Results in Managerial Decision-Making. Journal of Business Ethics, 8(10), 747-771.

Bageac, D., Furrer, O., Reynaud, E. (2010) Management Students' Attitudes Toward Business Ethics: A Comparison Between France and Romania. Journal of Business Ethics, 98:391-406

Betz, M., O'Connell, L. \& Shepard, J.M. (1989). Gender Differences in Proclivity for Unethical Behavior. Journal of Business Ethics, 8(5), 321-324.

Cohn, G. (1998). The Jewish View on Paying Taxes. Journal of Accounting, Ethics \& Public Policy, 1(2), 109-120, reprinted in R. W. McGee (Ed.), The Ethics of Tax Evasion (pp. 180-189). Dumont, NJ: The Dumont Institute for Public Policy Research, 1998.

Crowe, M. T. (1944). The Moral Obligation of Paying Just Taxes, The Catholic University of America Studies in Sacred Theology No. 84.

DeMoville, W. (1998). The Ethics of Tax Evasion: A Baha'i Perspective. Journal of Accounting, Ethics \& Public Policy, 1(3), 356-368, reprinted in R. W. McGee (Ed.), The Ethics of Tax Evasion (pp. 230240). Dumont, NJ: The Dumont Institute for Public Policy Research, 1998.

Dubinsky, A. J. \& Levy, M. (1985). Ethics in Retailing: Perceptions of Retail Sales People. Journal of the Academy of Marketing Science, 13(1), 1-16.

Englebrecht, T. D., Folami, B., Lee, C. \& Masselli, J.J. 1998. The Impact on Tax Compliance Behavior: a Multidimensional Analysis. Journal of Accounting, Ethics \& Public Policy, 1(4), 738-768, reprinted in R. W. McGee (Ed.), The Ethics of Tax Evasion (pp. 372-402). Dumont, NJ: The Dumont Institute for Public Policy Research, 1998.

Garcia. I., (1997), Dignidad - Ethics Through Hispanic Eyes, Abingdon Press: Nashville, TN

Glover, S. H., Bumpus, M., Logan, J.E. \& Ciesla, J.R. (1997). Re-examining the Influence of Individual Values on Ethical Decision Making. Journal of Business Ethics, 16(12/13), 1319-1329. 
Gronbacher, G.M.A. (1998). Taxation: Catholic Social Thought and Classical Liberalism. Journal of Accounting, Ethics \& Public Policy, 1(1): 91-100, reprinted in R. W. McGee (Ed.), The Ethics of Tax Evasion (pp. 158-167). Dumont, NJ: The Dumont Institute for Public Policy Research, 1998.

Hair, J. F., Anderson, R. E., Tatham, R., \& Black, W. C. (1995). Multivariate data analysis with readings ( $4^{\text {th }}$ ed.). Prentice Hall, NJ: Englewood Cliffs.

Harris, J. R. (1990). Ethical Values of Individuals at Different Levels in the Organizational Hierarchy of a Single Firm. Journal of Business Ethics, 9(9), 741-750.

Inglehart, R., Basanez, M., Diez-Medrano, J., Halman, L. \& and Luijkx, R. (Eds.). (2004). Human Beliefs and Values: a cross-cultural sourcebook based on the 1999-2002 values surveys. Mexico: Siglo XXI Editores.

Kelley, S.W., Ferrell, O.C. \& Skinner, S.J. (1990). Ethical Behavior among Marketing Researchers: An Assessment of Selected Demographic Characteristics. Journal of Business Ethics, 9(8), 681-688.

Kidwell, J. M., Stevens, R.E. \& Bethke, A.L. (1987). Differences in Ethical Perceptions between Male and Female Managers: Myth or Reality? Journal of Business Ethics, 6(6), 489-493.

Kirchler, E., Hoelzl, E., \& Wahl, I., (2008). Enforced Versus Voluntary Tax Compliance: The Slippery Slope" Framework. Journal of Economic Psychology, 29, 210-225

Longenecker, J. G., McKinney, J.A. \& Moore, C.W. (1989). Do Smaller Firms Have Higher Ethics? Business and Society Review, 71, 19-21.

Marta, J., Mullin, K., Singhapakdi, A., Attia, A. \& Vitell, S.J. (2004). Some Important Factors Underlying Ethical Decisions of Middle-Eastern Marketers. International Marketing Review, 21(1), 5367.

McGee, R. W. (1994). Is Tax Evasion Unethical? University of Kansas Law Review, 42(2), 411-435. Reprinted at http://ssrn.com/abstract $=74420$.

McGee, R. W. (1997). The Ethics of Tax Evasion and Trade Protectionism from an Islamic Perspective. Commentaries on Law \& Public Policy, 1, 250-262. Reprinted at http://ssrn.com/abstract=461397.

McGee, R. W. (Ed.) (1998a). The Ethics of Tax Evasion. Dumont, NJ: The Dumont Institute for Public Policy Research.

McGee, R. W. (1998b). The Ethics of Tax Evasion in Islam: A Comment. Journal of Accounting, Ethics \& Public Policy, 1(2), 162-168, reprinted in R. W. McGee (Ed.), The Ethics of Tax Evasion (pp. 214219). Dumont, NJ: The Dumont Institute for Public Policy Research, 1998.

McGee, R. W. (1998c). Christian Views on the Ethics of Tax Evasion. Journal of Accounting, Ethics \& Public Policy, 1(2), 210-225. Reprinted at http://ssrn.com/abstract=461398.

McGee, R. W. (1998d). Jewish Views on the Ethics of Tax Evasion. Journal of Accounting, Ethics \& Public Policy, 1(3), 323-336. Reprinted at http://ssrn.com/abstract=461399. 
McGee, R. W. (1998e). Ethical Views on Tax Evasion among Swedish CEOs: A Comment. Journal of Accounting, Ethics \& Public Policy, 1(3), 460-467. Reprinted at http://ssrn.com/abstract=713903.

McGee, R. W. (1999a). Is It Unethical to Evade Taxes in an Evil or Corrupt State? A Look at Jewish, Christian, Muslim, Mormon and Baha'i Perspectives. Journal of Accounting, Ethics \& Public Policy, 2(1), 149-181. Reprinted at http://ssrn.com/abstract=251469.

McGee, R. W. (1999b). Why People Evade Taxes in Armenia: A Look at an Ethical Issue Based on a Summary of Interviews. Journal of Accounting, Ethics \& Public Policy, 2(2), 408-416. Reprinted at http://ssrn.com/abstract $=242568$.

McGee, R. W. (2004). The Philosophy of Taxation and Public Finance. Boston, Dordrecht and London: Kluwer Academic Publishers.

McGee, R. W. (2005a). The Ethics of Tax Evasion: A Survey of International Business Academics. Presented at the $60^{\text {th }}$ International Atlantic Economic Conference, New York, October 6-9, 2005. Also available at www.ssrn.com.

McGee, R. W. (2005b). The Ethics of Tax Evasion: A Survey of Romanian Business Students and Faculty, Andreas School of Business Working Paper Series, Barry University, Miami Shores, FL 33161, USA, September. Available at www.ssrn.com. Reprinted in R. W. McGee \& G. G. Preobragenskaya, Accounting and Financial System Reform in Eastern Europe and Asia. New York: Springer, 2006.

McGee, R. W. (2006). The Ethics of Tax Evasion: A Case Study of Opinion in Thailand. 2006 Academy of International Business Southeast Asia Regional Conference, Bangkok, December 7-9. Reprinted at www.ssrn.com.

McGee, R. W., Alver, J. \& Alver, L. (2008). The Ethics of Tax Evasion: A Survey of Estonian Opinion, in R. W. McGee (Ed.), Taxation and Public Finance in Transition and Developing Economies (pp. 461480). New York: Springer.

McGee, R. W. \& Bernal, A. (2006). The Ethics of Tax Evasion: A Survey of Business Students in Poland. In M. Baliamoune-Lutz, A. Z. Nowak \& J. Steagall (Eds.), Global Economy - How It Works (pp. 155174). Warsaw: University of Warsaw \& Jacksonville: University of North Florida. Reprinted at www.ssrn.com.

McGee, R. W. \& Bose, S. (2009). The Ethics of Tax Evasion: A Survey of Australian Opinion, in R. W. McGee, Readings in Business Ethics (pp. 143-166). Hyderabad, India: ICFAI University Press.

McGee, R. W. \& Cohn, G. (2008). Jewish Perspectives on the Ethics of Tax Evasion. Journal of Legal, Ethical and Regulatory Issues, 11(2), 1-32 Reprinted at www.ssrn.com.

McGee, R. W., Ho, S.S.M. \& Li, A.Y.S. (2008). A Comparative Study on Perceived Ethics of Tax Evasion: Hong Kong vs. the United States. Journal of Business Ethics, 77(2), 147-158.

McGee, R. W. \& Noronha, C. (2008). The Ethics of Tax Evasion: A Comparative Study of Guangzhou (Southern China) and Macau Opinions. Euro Asia Journal of Management, 18(2), 133-152.

McGee, R. W. \& Tyler, M. (2007). Tax Evasion and Ethics: A Demographic Study of Thirty-three Countries. International Journal of Business, Accounting, and Finance, 1(1), 95-114. Reprinted at www.ssrn.com. 
Morales, A. (1998). Income Tax Compliance and Alternative Views of Ethics and Human Nature. Journal of Accounting, Ethics \& Public Policy, 1(3), 380-399, reprinted in R. W. McGee (Ed.), The Ethics of Tax Evasion (pp. 242-258). Dumont, NJ: The Dumont Institute for Public Policy Research, 1998.

Murtuza, A. \& Ghazanfar, S.M. (1998). Taxation as a Form of Worship: Exploring the Nature of Zakat. Journal of Accounting, Ethics \& Public Policy, 1(2), 134-161, reprinted in R. W. McGee (Ed.), The Ethics of Tax Evasion (pp. 190-212). Dumont, NJ: The Dumont Institute for Public Policy Research, 1998.

Nylén, U. (1998). Ethical Views on Tax Evasion among Swedish CEOs. Journal of Accounting, Ethics \& Public Policy, 1(3), 435-459, reprinted in R. W. McGee (Ed.), The Ethics of Tax Evasion (pp. 260-282). Dumont, NJ: The Dumont Institute for Public Policy Research, 1998.

Pennock, R. T. (1998). Death and Taxes: On the Justice of Conscientious War Tax Resistance. Journal of Accounting, Ethics \& Public Policy, 1(1), 58-76, reprinted in R. W. McGee (Ed.), The Ethics of Tax Evasion (pp. 124-142). Dumont, NJ: The Dumont Institute for Public Policy Research, 1998.

Posner, E.A., (2000) Law and Social Norms: The Case of Tax Compliance, Virginia Law Review, 86 (8), $1781-1819$

Preobragenskaya, G. G. \& McGee, R.W. (2004). Taxation and Public Finance in a Transition Economy: A Case Study of Russia. In C. Gardner, J. Biberman \& A. Alkhafaji (Eds.), Business Research Yearbook: Global Business Perspectives (Vol. XI, pp. 254-258). Saline, MI: McNaughton \& Gunn, Inc. A longer version, which was presented at the Sixteenth Annual Conference of the International Academy of Business Disciplines in San Antonio, March 25-28, 2004, is available at http://ssrn.com/abstract=480862

Reckers, P.M.J., Sanders, D.L. \& Roark, S.J. (1994). The Influence of Ethical Attitudes on Taxpayer Compliance. National Tax Journal, 47(4), 825-836.

Ruegger, D. \& King. E.W. (1992). A Study of the Effect of Age and Gender upon Student Business Ethics. Journal of Business Ethics, 11(3), 179-186.

Schansberg, D. E. (1998). The Ethics of Tax Evasion within Biblical Christianity: Are There Limits to 'Rendering Unto Caesar'? Journal of Accounting, Ethics \& Public Policy, 1(1), 77-90, reprinted in R. W. McGee (Ed.), The Ethics of Tax Evasion (pp. 144-157). Dumont, NJ: The Dumont Institute for Public Policy Research, 1998.

Slemrod, J.(2007). Cheating Ourselves: The Economics of Tax Evasion. Journa of Economic Perspectives, 21(1), 25-48

Smatrakalev, G. (1998). Walking on the Edge: Bulgaria and the Transition to a Market Economy. In R. W. McGee (Ed.), The Ethics of Tax Evasion (pp. 316-329). Dumont, NJ: The Dumont Institute for Public Policy Research, 1998.

Smith, S. R. \& Kimball, K.C. (1998). Tax Evasion and Ethics: A Perspective from Members of The Church of Jesus Christ of Latter-day Saints. Journal of Accounting, Ethics \& Public Policy, 1(3), 337348, reprinted in R. W. McGee (Ed.), The Ethics of Tax Evasion (pp. 220-229). Dumont, NJ: The Dumont Institute for Public Policy Research, 1998. 
Tamari, M. (1998). Ethical Issues in Tax Evasion: A Jewish Perspective. Journal of Accounting, Ethics \& Public Policy, 1(2), 121-132, reprinted in R. W. McGee (Ed.), The Ethics of Tax Evasion (pp. 168-178). Dumont, NJ: The Dumont Institute for Public Policy Research, 1998.

Torgler, B. (2003). Tax Morale: Theory and Empirical Analysis of Tax Compliance. Dissertation der Universität Basel zur Erlangung der Würde eines Doktors der Staatswissenschaften.

U.S. Department of the Treasury (no author attribution), Update on Reducing the Federal Tax Gap and Improving Voluntary Compliance, July 8, 2009 (pp. 1-31)

Vaguine, V. V. (1998). The 'Shadow Economy' and Tax Evasion in Russia. In R. W. McGee (Ed.), The Ethics of Tax Evasion (pp. 306-314). Dumont, NJ: The Dumont Institute for Public Policy Research, 1998.

Weeks, W. A., Moore, C.W., McKinney, J.A. \& Longenecker, J.G. (1999). The Effects of Gender and Career Stage on Ethical Judgment. Journal of Business Ethics, 20(4), 301-313.

\section{BIOGRAPHY}

Robert W. McGee is an associate professor in the School of Accounting at Florida International University. He can be contacted at School of Accounting, College of Business Administration, Florida International University, 3000 NE 151 Street, ACII-124, North Miami, FL 33181. E-mail: Robert.McGee@fiu.edu.

Arsen Djatej is Associate Professor of Accountancy at Eastern Washington University and specializes in Intermediate Accounting, Advanced Accounting, and International Accounting topics, Accounting Information Systems and MBA accounting. He can be contacted at Eastern Washington University, Department of Accounting and Information Systems, 668 N. Riverpoint Blvd, Suite A, Room 350, Spokane, WA 99202. E-mail: adjatej@ewu.edu

Robert H.S. Sarikas is Associate Professor of Accountancy at Ohio University. He teaches auditing and accountancy. His research includes topics in international accountancy and international taxation. He can be contacted at the Ohio University School of Accountancy, 614 Copeland, Athens, Ohio 45701. E-mail: sarikas@ohio.edu 